Maffulli N, Caine DJ (eds): Epidemiology of Pediatric Sports Injuries: Team Sports.

Med Sport Sci. Basel, Karger, 2005, vol 49, pp 31-61

\title{
Basketball Injuries
}

\author{
Peter A. Harmer \\ Exercise Science-Sports Medicine, Willamette University, Salem, Oreg., USA
}

\begin{abstract}
Objective:To identify and quantify, to the best extent possible from the existing literature, injury characteristics and factors (risk; protective) associated with injury in young basketball players. Data Sources: Database searches principally involving Medline and SportDiscus. In addition, web-based searching and filtering of the reference lists of papers found in the preliminary searches were utilized. Main Results: Few well-controlled studies of this population have been conducted. However, from the information available: basketball is the most frequent cause of sports-related emergency department visits for youth and adolescents; the risk of being injured in a game is greater than for practice; girls are more likely to be injured than boys, especially with knee and ankle injuries and the knee injuries are more likely to be severe; acute injuries are more common than chronic; strains/sprains are the most common types of injuries but overall time loss is minimal, indicating that the majority of pediatric basketball injuries are minor (less than 7 days away from activity). Intervention studies show that: mouthguards reduce orofacial/dental injuries; mouthguard use can be increased in young players; neuromuscular training can reduce the incidence of knee injuries in female participants; postural sway is related to risk of ankle injury. Conclusions: The current state of epidemiological research involving youth and adolescent basketball injuries is poor. With an increasing number of young participants, in situations ranging from informal play and physical education classes to organized community and school teams, the need for comprehensive and authoritative information on risk and protective factors is significant.
\end{abstract}

Copyright $(2005$ S. Karger AG, Basel

\section{Introduction}

Basketball is one of the most popular physical activities in the world: $11 \%$ of the world plays basketball and the Fédération Internationale de Basketball (FIBA), the international governing body of basketball, now represents 212 member nations and 450 million registered participants [1]. In the USA, basketball is the most popular team sport for boys and girls, with 544,811 boys and 
457,986 girls registered in the 2003-2004 school year [2]. Although the USA has long been considered the dominant force in basketball, recent results such as in the men's 1988 and 2004 Olympic Games and 2002 World Championships demonstrate that the rest of the world is closing the gap. The evolving parity at the upper echelon of the sport is only possible with the on-going growth of developmental programs for children and youth. Similarly, since the first women's world championship in 1953, many countries are providing opportunities for youngsters to learn the game in settings ranging from physical education classes and scholastic competition to governmental and private sports organizations and community recreational programs.

Unfortunately, as the number of young male and female participants has increased so has the number of injuries. For example, according to the National Electronic Injury Surveillance System - All Injury Program (NEISS-AIP) [3], basketball was the most common cause of sports- and recreation-related injuries seen at USA Emergency Departments in 2000-2001, with 395,251 cases. The proportion of cases was not evenly distributed across age groups for boys aged 5-9, basketball accounted for $4.9 \%$ of all sport injuries, whereas it constituted $15.2 \%$ of cases for boys aged $10-14$, and $25.9 \%$ for boys aged 15-19, the highest percentage for any activity in this group including football. For girls aged $10-14$, basketball produced $14.9 \%$ of all sports injuries and $18.1 \%$ in the $15-19$-year-old group.

Although the absolute number of injuries has implications for the healthcare system, the actual risk of injury in basketball is difficult to determine. The apparent age-related increases in injury in the NEISS-AIP may be simply a reflection of the number of players at each age level. Without knowing the number of participants, it is not possible to determine whether older children are more at risk and, if so, why. Similarly, even accurately identifying the extent of the problem is difficult. If NEISS data from physician offices and urgent-care clinics are incorporated, the number of basketball injuries in 5-14 year olds was estimated to be approximately 574,000 [4]. In either case, these data represent only $20-50 \%$ of the actual number of basketball injuries in participants aged under $18[3,5]$.

If effective interventions are to be instituted to reduce injuries in young players, accurate and reliable information is essential. However, the limited epidemiological data available center on college and professional athletes, although participation is much greater in scholastic competition [6]. Zvijac and Thompson [6] proposed that studying high school players would provide a clear understanding of the true nature of injuries in basketball because more data could be obtained from the larger population. Although this approach is reasonable, it assumes that etiological factors are static across the wide variety of player and playing characteristics, but both direct and indirect evidence 
indicates this is not the case. Physical, psychological, and social traits of five year olds are significantly different from those of 18 year olds, as are the demands of playing in physical education class, pick-up games, or organized competition in the Americas, Europe, Asia or Australia. Data from the appropriate stratification of gender, age, environment, and sociocultural factors are necessary to uncover, and effectively counter, the underlying risks of playing basketball.

This review identifies and evaluates the available literature on injuries in pediatric basketball. The primary search was limited to data-based studies in English derived from the Medline and SportDiscus databases, utilizing combinations of both general ('basketball', 'injury', 'youth, pediatric, children'), and specific terms ('catastrophic', 'eye', 'dental'). Secondary searching consisted of combing the reference lists of acceptable studies from the primary search and a previous review on basketball injuries [6], as well as a general web-based search using the same keywords.

Results demonstrated an overall lack of quality information for pediatric basketball injuries. A large number of hospital emergency department-based studies provided a general picture of the relative public health burden of basketball injuries but did not provide stratified age, injury type, location or severity data. For example, Watkins and Peabody [7] completed a 3-year retrospective study of sports injuries in athletes aged 5-17 treated at a sports injury clinic in London and found that, for males, basketball was eighth on a list of 10 sports ranked by the number of injuries reported, accounting for only $3.7 \%$ of injuries, while Boyce and Quigley [8] reported that basketball accounted for $7 \%$ of sports-related injuries in 5-16 year olds at a Scottish Emergency Department over a 3-month period.

However, in a similar study in Hong Kong over a 6-year period, basketball accounted for $15.5 \%$ ( 37 of 238 cases) of all sports-related injuries in children younger than 16 years old, the most of any sport [9], as was the finding from a 6-year study at the national Olympic Training Center in Puerto Rico for athletes 10-19 years old [10]. Unfortunately, none of these studies presented exposure information; so it is impossible to determine whether the differences were due to the popularity of basketball in each location, or whether there is a causal mechanism operating that makes playing basketball 'riskier' in Hong Kong and Puerto Rico than in England or Scotland.

Methodological problems in hospital-based studies, include: (1) focus is often not on specific sports, (2) lack of a universal definition of injury making comparison across studies difficult, (3) no distinction between formal and recreational activities, (4) no denominator data (reference population), and (5) the metric for incidence rates is not standardized. In the majority of these, and similar school- or club-based studies, basketball-specific information about 
age, gender, and injury characteristics is inextricably embedded in broader analytical categories [11]. In addition, many references are out-dated as the nature of basketball has changed (from noncontact to contact), and younger age groups are generally not included [12].

Given the impact of basketball across the globe, the dearth of methodologically sound injury research on young players is surprising. If suitable preventative and protective measures are to evolve, future work needs to include a clear understanding of the population at risk, definitive criteria for a reportable injury, and the capacity to calculate exposure time and time loss.

\section{Incidence of Injury}

Delineating the risk of injury in sport is based on establishing the incidence, i.e., the number of new cases that occur in a particular population over a given time. Although the number of cases alone can be informative [13], incidence is considered the gold standard of the measure of risk. A comparison of injury rates from prospective and retrospective research is shown in table 1 and covers high school [14-21], physical education class [22], clubs/sports organizations [23-27], and hospital emergency departments [28, 29]. In addition, studies reporting incidence data specifically for knee [18, 19, 30], ankle [31, 32], head [33], and orofacial [34-36] injuries are listed. Unfortunately, the injury literature on youth basketball suffers from a broad range of methodological shortcomings, including widely varying definitions of a reportable injury, limited measures of exposure, differing metrics of risk, and poor delineation of the population at risk. Consequently, it is very difficult to get a clear picture of the risk inherent in basketball, or the particular risks associated with gender, age, level of skill, playing conditions, etc. Although some studies have been well designed, the lack of a coordinated research program has produced a somewhat fragmented picture from which only broad conclusions may be drawn.

For example, the 1997-1998 National Hospital Ambulatory Medical Care Survey (NHAMCS) of emergency department admissions for ages 5-24 (40\% aged 5-14) showed that basketball was the most frequently cited reason for sport-related emergency department visits (17.1\%), with a calculated incidence rate of 5.8 per $1,000(95 \% \mathrm{CI}=4.7-6.8)$ persons in the general population [37]. Although the 1997-1999 National Health Interview Survey (NHIS) had a $36.2 \%$ difference in the number of reported basketball injuries with NHAMCS, it confirmed basketball as the most common cause of sports injury for ages $5-24$, with a rate of 3.9 per 1,000 persons $(95 \% \mathrm{CI}=3.3-4.5)$ in the general population. However, for the group ages 5-14, basketball had an incidence rate of 6.5 per 1,000 persons $(95 \% \mathrm{CI}=4.7-8.3)$ [38]. NHIS also found that $42 \%$ 
Table 1. A comparison of injury rates among young basketball players

\begin{tabular}{|c|c|c|c|c|c|c|c|c|c|}
\hline Study & $\begin{array}{l}\text { Design } \\
\text { Prospective/ } \\
\text { Retrospective } \\
\text { (P) (R) }\end{array}$ & $\begin{array}{l}\text { Data collection } \\
\text { Direct monitor } \\
\text { (DM), Interview } \\
\text { (I), Record } \\
\text { review (RR), } \\
\text { Questionnaire (Q) }\end{array}$ & $\begin{array}{l}\text { Duration } \\
\text { of study }\end{array}$ & Team type & $\begin{array}{l}\text { Number of } \\
\text { injuries } \\
\text { (definition } \\
\text { varies } \\
\text { greatly) }\end{array}$ & $\begin{array}{l}\text { Number of } \\
\text { participants }\end{array}$ & $\begin{array}{l}\text { Injury rate } \\
\text { per } 100 \\
\text { participants }\end{array}$ & $\begin{array}{l}\text { Injury } \\
\text { rate } \\
\text { per } 1,000 \\
\text { hours of } \\
\text { exposure }\end{array}$ & $\begin{array}{l}\text { Injury rate } \\
\text { per } 1,000 \\
\text { AE }\end{array}$ \\
\hline $\begin{array}{r}\text { Chandy and } \\
\text { Grana [14] }\end{array}$ & $?$ & $\mathrm{RR}$ & $\begin{array}{l}3 \text { years } \\
(1978-1981)\end{array}$ & $\begin{array}{l}\text { High school } \\
(\mathrm{n}=130) \\
\text { (USA) }\end{array}$ & $\begin{array}{l}404 \text { (boys) } \\
498 \text { (girls) }\end{array}$ & $\begin{array}{l}7,209 \text { (boys) } \\
6,426 \text { (girls) }\end{array}$ & $\begin{array}{l}5.6 \\
7.8\end{array}$ & $\begin{array}{l}- \\
-\end{array}$ & $\begin{array}{l}- \\
-\end{array}$ \\
\hline $\begin{array}{l}\text { McLain and } \\
\text { Reynolds [15] }\end{array}$ & $\mathrm{P}$ & $\mathrm{DM}$ & $\begin{array}{l}1 \text { year } \\
(1987-1988)\end{array}$ & $\begin{array}{l}\text { High school } \\
(\mathrm{n}=1) \\
\text { (USA) }\end{array}$ & $\begin{array}{l}21 \text { (boys) } \\
14 \text { (girls) }\end{array}$ & $\begin{array}{l}57 \text { (boys) } \\
45 \text { (girls) }\end{array}$ & $\begin{array}{l}36.8 \\
31.0\end{array}$ & $\begin{array}{l}- \\
-\end{array}$ & $\begin{array}{l}- \\
-\end{array}$ \\
\hline $\begin{array}{l}\text { DuRant } \\
\text { et al. [16] }\end{array}$ & $\mathrm{R}$ & Q & $\begin{array}{l}1 \text { year } \\
(1989-1990)\end{array}$ & $\begin{array}{l}\text { High school } \\
(\mathrm{n}=\text { multiple) } \\
\text { (USA) }\end{array}$ & $\begin{array}{l}20 \text { (boys) } \\
32 \text { (girls) }\end{array}$ & $\begin{array}{l}132 \text { (boys) } \\
96 \text { (girls) }\end{array}$ & $\begin{array}{l}15.2 \\
33.3\end{array}$ & $\begin{array}{l}- \\
-\end{array}$ & $\begin{array}{l}- \\
-\end{array}$ \\
\hline $\begin{array}{l}\text { Gomez } \\
\text { et al. [17] }\end{array}$ & $\mathrm{P}$ & $\mathrm{DM}$ & $\begin{array}{l}1 \text { year } \\
(1993-1994)\end{array}$ & $\begin{array}{l}\text { High school } \\
(\mathrm{n}=100) \\
\text { (USA) }\end{array}$ & 436 & 890 (girls) & 49 & 4 & - \\
\hline $\begin{array}{l}\text { Messina } \\
\text { et al. [18] }\end{array}$ & $\mathrm{P}$ & DM & $\begin{array}{l}1 \text { season } \\
(1996-1997)\end{array}$ & $\begin{array}{l}\text { High school } \\
(\mathrm{n}=100) \\
\text { (USA) }\end{array}$ & $\begin{array}{l}543 \\
436\end{array}$ & $\begin{array}{l}973 \text { (boys) } \\
890 \text { (girls) }\end{array}$ & $\begin{array}{l}- \\
-\end{array}$ & $\begin{array}{l}3.2 \\
3.6\end{array}$ & $\begin{array}{l}- \\
-\end{array}$ \\
\hline $\begin{array}{l}\text { Powell and } \\
\text { Barber-Foss } \\
{[19]}\end{array}$ & $\mathrm{P}$ & $\mathrm{DM}$ & $\begin{array}{l}3 \text { years } \\
(1995-1997)\end{array}$ & $\begin{array}{l}\text { High school } \\
(\mathrm{n}=246) \\
\text { (USA) }\end{array}$ & $\begin{array}{l}1,933 \text { (boys) } \\
1,748 \text { (girls) }\end{array}$ & $\begin{array}{l}6,831 \text { (boys) } \\
6,083 \text { (girls) }\end{array}$ & $\begin{array}{l}28.3 \text { (boys) } \\
28.7 \text { (girls) }\end{array}$ & $\begin{array}{l}- \\
-\end{array}$ & $\begin{array}{l}- \\
-\end{array}$ \\
\hline $\begin{array}{l}\text { Beachy } \\
\text { et al. [20] }\end{array}$ & $\mathrm{P}$ & DM & $\begin{array}{l}8 \text { years } \\
(1988-1996)\end{array}$ & $\begin{array}{l}\text { High school } \\
\text { private } \\
\text { (USA) }\end{array}$ & $\begin{array}{l}505 \text { (boys) } \\
467 \text { (girls) }\end{array}$ & $\begin{array}{l}541 \text { (boys) } \\
587 \text { (girls) }\end{array}$ & $\begin{array}{l}93 \\
80\end{array}$ & $\begin{array}{l}- \\
-\end{array}$ & $\begin{array}{l}- \\
-\end{array}$ \\
\hline $\begin{array}{l}\text { Weir and } \\
\text { Watson [21] }\end{array}$ & $\mathrm{R}$ & Q & $\begin{array}{l}1 \text { year } \\
\text { (?Mid-1990s?) }\end{array}$ & $\begin{array}{l}\text { High school } \\
\text { (IRL) }\end{array}$ & 22 & $?$ & - & 5.6 & - \\
\hline $\begin{array}{l}\text { Backx } \\
\text { et al. [22] }\end{array}$ & $\mathrm{P}$ & DM;RR & $\begin{array}{l}7 \text { months } \\
(1982-1983)\end{array}$ & $\begin{array}{l}\text { PE classes/club } \\
\text { (ages 8-16) } \\
\text { (NED) }\end{array}$ & - & $\begin{array}{l}\text { Mixed } \\
\text { activity } \\
\text { population }\end{array}$ & $99.8 *$ & $\begin{array}{l}<5 \\
\text { (practice) } \\
23 \text { (game) }\end{array}$ & - \\
\hline
\end{tabular}


Table 1 (continued)

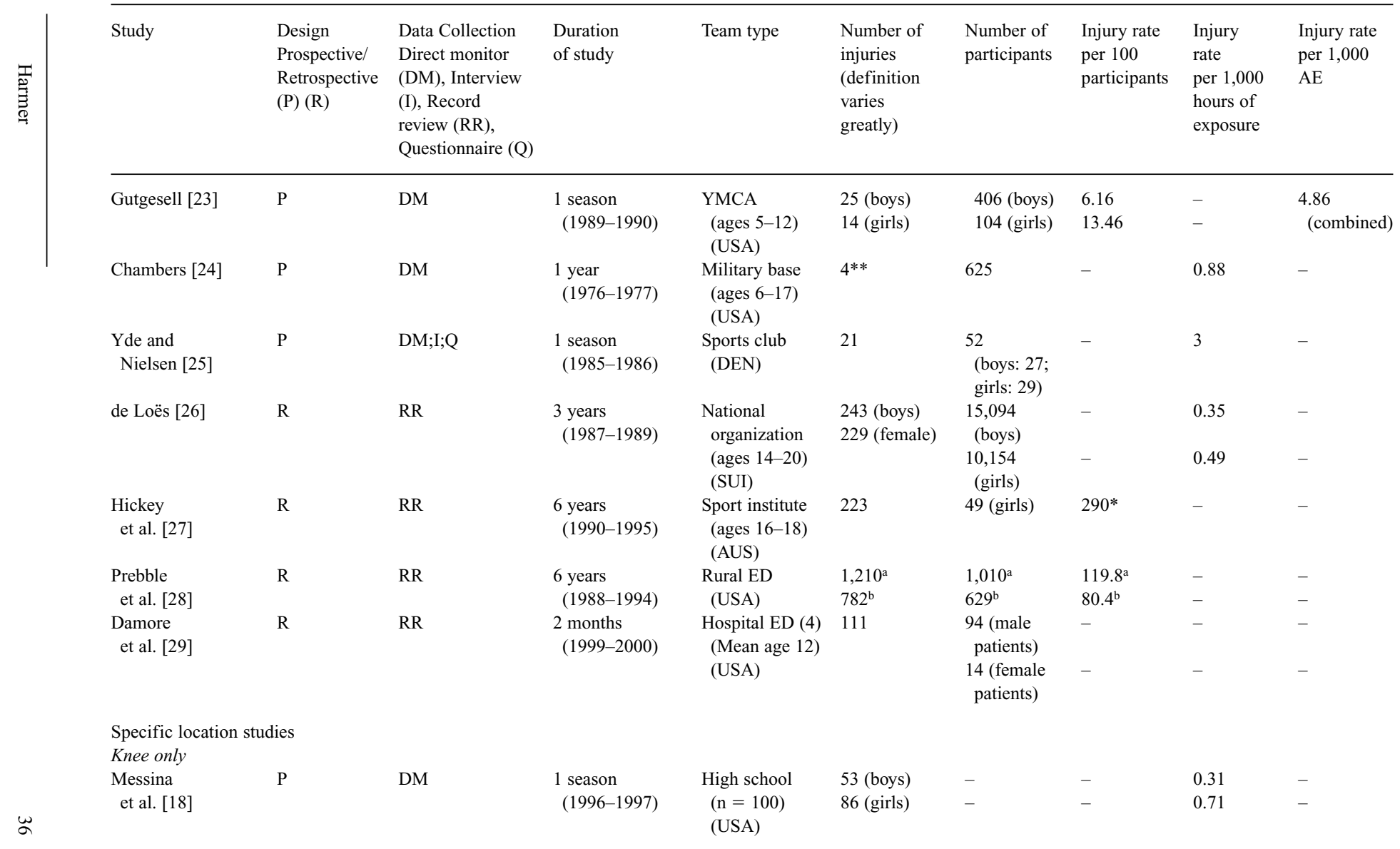




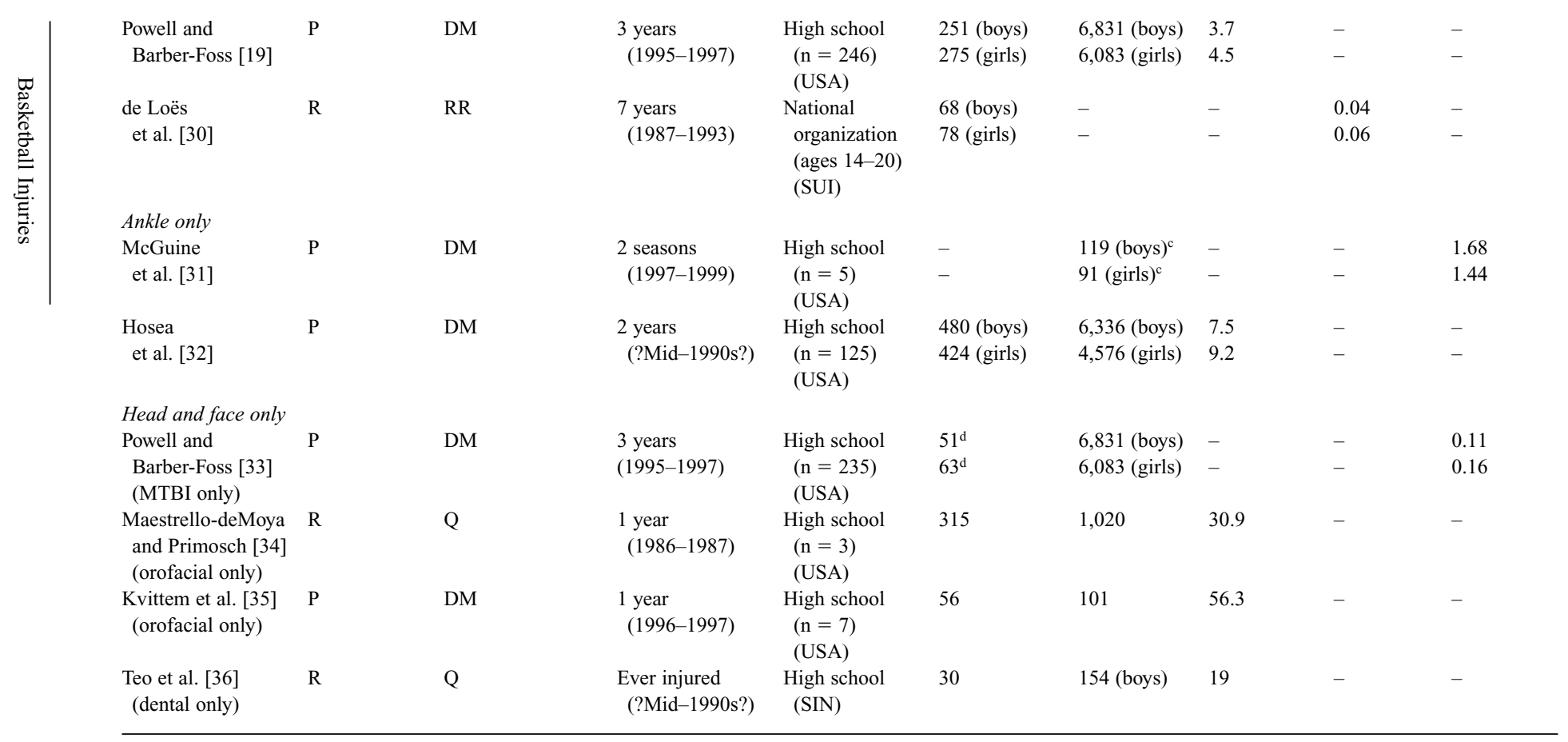

*per 100 participants per year - very broad definition of injury.

**Significant orthopedic injuries only.

${ }^{a}$ Includes $12.1 \%$ aged $20-29$.

${ }^{\mathrm{b}}$ Aged $<19$ years old.

'Specifically selected group for prevention study (asymptomatic, no time loss ankle or knee injuries for 12 months).

${ }^{\mathrm{d}}$ Reportable if evaluated. 
of this age group did not attend an emergency department for treatment. Nonetheless, the two studies provide some framework for understanding the injury characteristics for young basketball players. Additionally, Kelm et al. [39] reported that basketball accounted for $19.6 \%$ of injuries in physical education classes in Germany in children 11-15 years old, and studies from Dutch and Swiss schools indicated that basketball has a relative risk of 1.3 (95\% CI $=1.2-1.4)$ to 1.99 compared to the mean rate of all sports injuries recorded $[11,40]$.

The data in table 1 highlight the difficulty of gaining an accurate impression of the risks in youth basketball. Definitions of reportable injury range from any incident evaluated to incidents that result in at least 2 days absence, and the metric of risk include percentage injured, injuries per 1,000 hours of exposure or per 1,000 athlete exposures. Moreover, with the variety of ages in disparate settings (school teams, clubs, physical education classes) across multiple countries, there is little appropriately comparable data. Even the results of the most commonly studied population (American public high school players) vary considerably, from 5.6-36.8 per 100 participants for boys, and $7.8-49$ per 100 participants for girls [14-17, 19], although two studies which report injuries per 1,000 hours of participation are similar (3.2-4.0) [17, 18]. A coordinated research program with standard protocols is necessary if a clear picture of the level of risk, and associated causal factors, is to emerge.

\section{Injury Characteristics}

\section{Injury Onset}

There are few data available to determine the relative risk of sustaining an acute versus a chronic injury in youth basketball. However, two studies with significantly differing populations support the proposition of a greater risk of acute injury. Weir and Watson [21] found a relative risk of acute to chronic injury of 2.5:1 in a one year study of Irish high schools students (average age 14 years, with 4.02 acute injures per $1,000 \mathrm{~h}$ of participation vs. 1.61 chronic injuries per $1,000 \mathrm{~h}$ participation). Similarly, a 6 year study of elite females (average age 17 years) at a national training center in Australia evidenced an average acute-chronic injury ratio of 1.66:1 (range 0.88:1-2.9:1) [27].

\section{Injury Location}

A percent comparison of injury location in youth basketball is shown in table $2[12,17-19,25,27,29,41-43]$. The lower extremities generally account for the majority of injuries in youth basketball (35.9-92\%), with the ankle/foot representing the single most frequently injured region $(16.6-44 \%)[12,17-19$, 
Table 2. A percent comparison of injury location in youth basketball

\begin{tabular}{|c|c|c|c|c|c|c|c|c|c|}
\hline \multirow[t]{2}{*}{ Location } & \multirow{2}{*}{$\begin{array}{l}\text { Taylor and } \\
\text { Attia } \\
{[12]} \\
(\mathrm{n}=132)\end{array}$} & \multirow{2}{*}{$\begin{array}{l}\text { Gomez } \\
\text { et al. } \\
{[17]} \\
(\mathrm{n}=890)\end{array}$} & \multicolumn{2}{|l|}{$\begin{array}{l}\text { Messina } \\
\text { et al. } \\
{[18]}\end{array}$} & \multicolumn{2}{|l|}{$\begin{array}{l}\text { Powell and } \\
\text { Barber-Foss } \\
{[19]}\end{array}$} & \multirow{2}{*}{$\begin{array}{l}\text { Yde and } \\
\text { Nielsen } \\
{[25]} \\
(n=21)\end{array}$} & \multirow{2}{*}{$\begin{array}{l}\text { Hickey } \\
\text { et al. } \\
{[27]} \\
(\mathrm{n}=223)\end{array}$} & \multirow{2}{*}{$\begin{array}{l}\text { Damore } \\
\text { et al. } \\
\text { [29] } \\
(\mathrm{n}=111)\end{array}$} \\
\hline & & & $\begin{array}{l}\text { boys } \\
(\mathrm{n}=543)\end{array}$ & $\begin{array}{l}\text { girls } \\
(\mathrm{n}=436)\end{array}$ & $\begin{array}{l}\text { boys } \\
(\mathrm{n}=1,933)\end{array}$ & $\begin{array}{l}\text { girls } \\
(\mathrm{n}=1,748)\end{array}$ & & & \\
\hline $\begin{array}{l}\text { Head/Spine/ } \\
\text { Trunk }\end{array}$ & (11.4) & (14) & (20) & (14) & $(21.3)$ & (18.7) & - & (20.7) & (7) \\
\hline Skull & 10.7 & 3 & 3 & 3 & - & - & - & 5.8 & 2 \\
\hline Face & $\begin{array}{l}\text { (including } \\
\text { face) }\end{array}$ & 4 & 11 & 5 & $\begin{array}{l}10 \\
\text { (including sc }\end{array}$ & p) & - & $\begin{array}{l}\text { (including } \\
\text { face) }\end{array}$ & 3 \\
\hline Teeth & - & - & - & - & & & - & - & \\
\hline Neck & - & - & - & - & - & - & - & - & - \\
\hline Back & - & 6 & 6 & 6 & - & - & - & 14.9 & 2 \\
\hline $\begin{array}{l}\text { Upper } \\
\text { extremity }\end{array}$ & (48.9) & (15) & (16) & (14) & (13.8) & (12.8) & (43) & (13.0) & (35) \\
\hline Shoulder & 1.5 & 5 & 4 & 3 & 2.4 & 2.4 & - & 3.1 & 1 \\
\hline Arm & - & - & - & - & - & - & - & $\begin{array}{l}\text { (including } \\
\text { arm/elbow) }\end{array}$ & - \\
\hline Elbow & - & - & - & - & - & - & - & - & - \\
\hline Forearm & - & - & - & - & 11.4 & 10.4 & - & - & 13 \\
\hline Wrist & $\begin{array}{l}36.7 \\
\text { (including } \\
\text { hand) }\end{array}$ & 2 & 3 & 3 & (including $\mathrm{w}$ & t/hand) & - & $\begin{array}{l}9.9 \\
\text { (including } \\
\text { hand) }\end{array}$ & $\begin{array}{l}\text { (including } \\
\text { wrist) }\end{array}$ \\
\hline $\begin{array}{l}\text { Hand/ } \\
\text { Fingers }\end{array}$ & & 8 & 9 & 8 & - & - & 43 & & 21 \\
\hline
\end{tabular}




\begin{tabular}{|c|c|c|c|c|c|c|c|c|c|c|c|}
\hline \multirow[t]{2}{*}{ Location } & \multirow{2}{*}{$\begin{array}{l}\text { Taylor and } \\
\text { Attia [12] } \\
(\mathrm{n}=132)\end{array}$} & \multirow{2}{*}{$\begin{array}{l}\text { Gomez } \\
\text { et al. [17] } \\
(\mathrm{n}=890)\end{array}$} & \multicolumn{2}{|c|}{$\begin{array}{l}\text { Messina } \\
\text { et al. [18] }\end{array}$} & \multicolumn{4}{|c|}{$\begin{array}{l}\text { Powell and } \\
\text { Barber-Foss [19] }\end{array}$} & \multirow{2}{*}{$\begin{array}{l}\text { Yde and } \\
\text { Nielsen } \\
{[25]} \\
(\mathrm{n}=21)\end{array}$} & \multirow{2}{*}{$\begin{array}{l}\text { Hickey } \\
\text { et al. [27] } \\
(\mathrm{n}=223)\end{array}$} & \multirow{2}{*}{$\begin{array}{l}\text { Damore } \\
\text { et al. [29] } \\
(\mathrm{n}=111)\end{array}$} \\
\hline & & & $\begin{array}{l}\text { boys } \\
(\mathrm{n}=543\end{array}$ & $\begin{array}{l}\text { girls } \\
(\mathrm{n}=436)\end{array}$ & \multicolumn{2}{|c|}{$\begin{array}{l}\text { boys } \\
(\mathrm{n}=1,933)\end{array}$} & \multicolumn{2}{|c|}{$\begin{array}{l}\text { girls } \\
(\mathrm{n}=1,748)\end{array}$} & & & \\
\hline $\begin{array}{l}\text { Lower } \\
\text { extremity }\end{array}$ & $(37.1)$ & (69) & $(61)$ & (69) & \multicolumn{2}{|l|}{$(64.8)$} & \multicolumn{2}{|c|}{$(68.7)$} & (43) & $(62.4)$ & $(58)$ \\
\hline Pelvis/Hips & - & 10 & 11 & 9 & \multicolumn{2}{|l|}{-} & \multicolumn{2}{|l|}{-} & \multirow{2}{*}{-} & \multirow{2}{*}{$\begin{array}{l}6.3 \\
\text { (including } \\
\text { thigh) }\end{array}$} & - \\
\hline Thigh & - & $\begin{array}{l}\text { (including } \\
\text { thigh) }\end{array}$ & \multicolumn{2}{|c|}{ (including thigh) } & - & & \multicolumn{2}{|l|}{-} & & & 1 \\
\hline Knee & - & 19 & 10 & 20 & \multicolumn{2}{|l|}{11.1} & \multicolumn{2}{|c|}{15.7} & 5 & 18.8 & 7 \\
\hline Leg & - & 4 & 4 & 4 & \multicolumn{2}{|l|}{-} & \multicolumn{2}{|c|}{-} & - & 10.8 & 6 \\
\hline Ankle & 33.3 & 31 & 32 & 31 & \multirow{2}{*}{\multicolumn{4}{|c|}{$\begin{array}{l}39.3 \quad 36.6 \\
\quad \text { (including foot) }\end{array}$}} & 33 & 16.6 & \\
\hline \multirow[t]{2}{*}{ Foot/Toes } & $\begin{array}{l}\text { (including } \\
\text { foot) }\end{array}$ & 5 & 4 & 5 & & & & & - & 9.9 & $\begin{array}{l}\text { (including } \\
\text { foot) }\end{array}$ \\
\hline & $2.7 \%$ other & \multicolumn{7}{|c|}{$2 \%$ not listed $(3 \%$ other $)$} & $14 \%$ other & \multicolumn{2}{|l|}{$4 \%$ chest } \\
\hline \multirow[t]{3}{*}{ Location } & \multicolumn{4}{|c|}{ NATA [41] } & \multicolumn{6}{|c|}{ Belechri et al. [42] } & \multirow{3}{*}{$\begin{array}{l}\text { Finch et al. } \\
{[43]} \\
(\mathrm{n}=3,722)\end{array}$} \\
\hline & $1986-1 \mathrm{~s}$ & & $1995-19$ & & DEN & FR & & GRE & NED & UK & \\
\hline & boys & girls & boys & girls & & & & & & & \\
\hline $\begin{array}{l}\text { Head/Spine/ } \\
\text { Trunk }\end{array}$ & - & - & $(12.2)$ & $(8.8)$ & (4.6) & $(5$. & & (8.8) & (6) & $(8.2)$ & (14.4) \\
\hline Skull & - & - & - & - & - & - & & - & - & - & - \\
\hline Face & - & - & 12.2 & 8.8 & 2.7 & 3.1 & & 6.2 & 4 & 6.3 & - \\
\hline
\end{tabular}




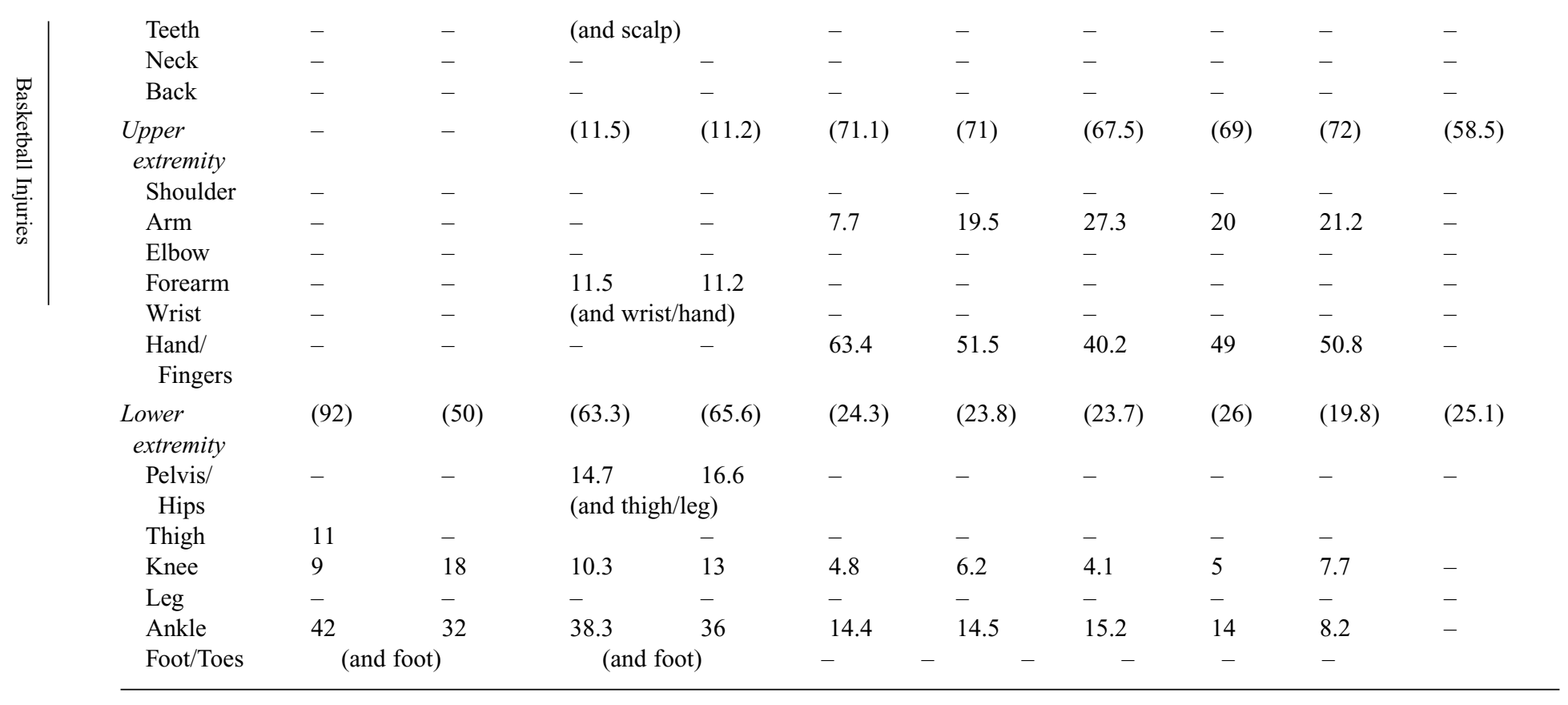


$23,25,27-29,41]$. The knee is the second most frequently injured area in the lower extremity (5-20\%) [17-19, 25, 27, 29, 41] but with noticeable gender differences, ranging from $9-11.1 \%$ for boys to $13-20 \%$ for girls [18, 19, 41]. In a stark comparison, Belechri et al. [42], reporting data from five European Union countries, indicated a range for total lower extremities injuries of $19.8-26 \%$, with ankle/foot injuries contributing just $8.2-15.2 \%$ of all injuries, and knee injuries ranging from $4.1-7.7 \%$ of the total. An Australian study similarly reported lower extremity injuries accounting for only $25.1 \%$ [43].

The reversal of findings is repeated in upper extremities data with most studies reporting between $11-16 \%[17-19,27,41]$ or $35-49 \%[12,25,29]$ of injuries occurring in this region in contrast to Belechri et al. [42] with values from $67.5-72 \%$ and Finch et al. [43] at 58.5\%. The majority of upper extremities injuries in Belechri et al.'s [42] study were to the hand/fingers (40.2-63.4\%), in line with additional studies, particularly involving younger children $(13 \%$ [23]; $13.7 \%$ of acute injuries [27]; $17 \%$ [44]; 19.3\% [28]; $21 \%$ [29]; 43\% [25]). Taylor and Attia [12] found that wrist/hand injuries were more likely in basketball than in any other sport studied ( $\mathrm{OR}=1.7 ; 95 \% \mathrm{CI}=1.1-2.5)$. However, the reason for the extreme deviation of the European and Australian data is not evident.

The percentage of injuries to other body areas, particularly the head, varies between $7-21 \%$. Head injuries producing mild traumatic brain injury (MTBI) have been found to account for approximately 2.6 and 3.6\% of all basketball injuries in males and females, respectively [33]. Face and mouth injuries vary between $3-12.2 \%$ of all injuries [12, 18, 27, 29, 41] with the nose (epistaxis in $12.8 \%$ of all injuries [23]) and teeth apparently the most vulnerable [17, 35, 45, 46]. Finally, Wan et al. [47] reported that, from data in the National Pediatric Trauma Registry (1990-1999), basketball accounted for 9.4\% of significant abdominal injuries (18 of 191 cases) reported in 5-18 year olds. The kidneys and spleen were most at risk [5 cases (28\%) each]. There was one liver injury and the other 7 were nonspecific abdominal injuries.

\section{Situational}

The risk of injury is significantly greater in games than in practice. Estimates vary greatly, depending on the characteristics of the study. For example, in a study of children aged 5-12 in a community program, $90 \%$ of injuries were game-related, with a relative risk of 16.9:1 [23]. However, 6-18 year olds in a Danish sports club showed a game:practice relative risk of 2.4:1 (games $=5.7$ injuries per $1,000 \mathrm{~h}$ of participation; practice $=2.4$ ) [25]. Two studies of high school players in the USA produced a relative risk of 6.8:1 for female players in a 100-school sample [17], and an Incidence Density Ratio (IDR; game injury rate over practice injury rate) of 8.0 and 9.4 , for boys and girls, respectively 
$(\mathrm{p}<0.0001)$ [18]. Two additional high school studies provide further support by reporting the percentages of injuries in games and practices [19, 41]. Although no exposure data are provided, even a conservative estimate of 3 practices per game played indicate that the relative risk is approximately 2.2:1 for boys and between 2.1-2.8 for girls. Moreover, this relationship proved to be relatively consistent over time. Comparison of the 1986-1988 and 1995-1997 NATA [41] studies shows a game:practice relative risk for boys of 2.0 and 2.2, respectively, and 2.1 and 2.6 for girls, respectively (under the assumption of 3 practices per game played), although the risk in games may be rising for girls.

The higher risk of injuries in games is also reflected in data related to particular types of injuries in high school athletes, including orofacial injuries (1.8:1) [35] and MTBI IDR $=4.9$ (95\% CI: 2.9-8.1) for boys and 6.1 (95\% CI: 3.8-9.7) for girls [33].

Two hospital-based studies, one from Denmark [48] and one from the USA [28], indicate that other situational factors need to be considered. Although both found that games and practices still accounted for the majority of basketball injuries seen (22.5 and 43\%, respectively, in the Danish study and 42.9 and $37.5 \%$, respectively, in the USA study), Sorensen et al. [48] found that free play or school activity accounted for $34.2 \%$ of the injuries treated, while Prebble et al. [28] noted that $9.6 \%$ came from physical education classes and $5.4 \%$ from intramurals or recess play.

\section{Action or Activity}

A broad set of actions has been identified in relation to injury in pediatric basketball, including colliding with another player (38.6\%) [12]; (36.7\%) [28]; (MTBI) [33], running (33\%) [19, 25], shooting $(29 \%)$ [19, 25], rebounding [19]; MTBI (girls) [33]; anterior cruciate ligament (ACL) injuries $(88.55 \%$ boys; $60 \%$ girls) [49]; (26\% boys; $30.8 \%$ girls) [41], twisting/turning $(31.8 \%)$ [12], scrambling for loose balls (34.4\% boys; $36.3 \%$ girls) [41] and controlled pattern activity (27.8\% boys; $32.6 \%$ girls) [41].

A number of specific interactions have also been noted. Yde and Nielsen [25] found that, although only $29 \%$ of injuries occurred while shooting, it accounted for $60 \%$ of ankle injuries. Powell and Barber-Foss [19] found that boys had more shooting-related injuries in games whereas girls had more dribbling-related injuries. Piasecki et al. [49] reported that the majority of ACL injuries (62\% for boys; $71 \%$ for girls) involved no contact with other players.

\section{Chronometry}

Few studies have documented the relationship of time factors to injuries. From the sparse information available, the risk of injury may be greater early 
in the season or late in games. A study of knee injuries in female high school programs found that most injuries occurred in the first half of the season [50]. The possible influence of fatigue as a risk factor is gleaned from studies in two disparate populations $-40.7 \%$ of all injuries in a YMCA program for young children occurred in last quarter of games [23], while a 3-year study of high school players found that $59 \%$ of injuries in boys' games and $63 \%$ in girls' games came in the second half [41].

\section{Injury Severity}

\section{Injury Type}

A percent comparison of injury types across high schools [17-19, 41], clubs/sporting organizations [23, 25-27], and hospital emergency departments $[12,29,42,43]$ is shown in table 3 . Sprains $[18,19,26,27,29,41,42]$ or sprains/strains [12, 17, 23, 28, 43] are the most common type of injury suffered by young basketball players, representing between $22-65.5 \%$ of all injuries. Strains account for approximately $16 \%$ of all reported injuries (range $13.3-17.7 \%)[19,41]$. Basketball players were more likely to sustain sprain or strains that any other sport monitored (football, baseball/softball, rollerblading/skating soccer, hockey) in a study at a large emergency department $(\mathrm{OR}=2.6 ; 95 \% \mathrm{CI}: 1.7-3.9)$ [12]. In a similar study, in a mixed sample $(77.8 \%<$ age 19$), 55.1 \%$ of basketball injuries were sprain/strains [28]. In a more in-depth analysis of knee injuries, de Loës et al. [30] found that in boys $21 \%$ of knee injuries were meniscal tears, $19 \%$ were ACL/posterior cruciate ligament (PCL) ruptures, $10 \%$ were medial/lateral collateral ligament tears and $32 \%$ were nonspecific ruptures. However, for girls, only $13 \%$ were meniscal tears with $18 \% \mathrm{ACL} / \mathrm{PCL}$ ruptures but $21 \%$ were medial/lateral collateral ligament tears. Patellar luxation was $13 \%$ of all knee injuries for girls compared to $4 \%$ for boys.

Overall, soft tissue injuries (contusions and abrasions) were the next most common type(s) of injuries reported, accounting for $15-36 \%$ of cases [17, 18, $23,26,29,41,43$ ], although Belechri et al. [42] reported a range of $17.4-55 \%$ in five European countries. This group also reported the greatest percentage of fractures (17-36\%), possibly due to the high number of hand/finger injuries reported. Generally, the range for fractures was $2.6-17.7 \%$ [17-19, 23, 26-28] although three studies reported fractures making up $26-28 \%$ of the total number of injuries [12, 29, 43]. Inflammatory conditions were rarely reported but Hickey et al. [27] found medial tibial stress syndrome to be responsible for $33.3 \%$ of all lower extremity injuries in a study of elite junior females, with patellar tendinopathy the most common knee problem (35.7\%). 
Table 3. A percent comparison of injury types in youth basketball players

\begin{tabular}{|c|c|c|c|c|c|c|c|c|c|c|c|c|c|}
\hline Study & $\begin{array}{l}\text { Number of } \\
\text { participants }\end{array}$ & $\begin{array}{l}\text { Number } \\
\text { of injuries }\end{array}$ & Abrasions & $\begin{array}{l}\text { Concussions/ } \\
\text { Neuro }\end{array}$ & $\begin{array}{l}\text { Contu- } \\
\text { sion }\end{array}$ & $\begin{array}{l}\text { Luxa- } \\
\text { tions }\end{array}$ & $\begin{array}{l}\text { Frac- } \\
\text { tures }\end{array}$ & $\begin{array}{l}\text { Inflamma- } \\
\text { tion }\end{array}$ & $\begin{array}{l}\text { Lacera- } \\
\text { tions }\end{array}$ & $\begin{array}{l}\text { Nonspe- } \\
\text { cific }\end{array}$ & Sprain & Strain & $\begin{array}{l}\text { Other/ } \\
\text { Unknown }\end{array}$ \\
\hline \multicolumn{14}{|l|}{ High schools } \\
\hline $\begin{array}{l}\text { Gomez } \\
\text { et al. [17] }\end{array}$ & 890 (girls) & 436 & - & 2 & 15 & 2 & 6 & - & 2 & - & $\begin{array}{l}56 \\
\text { (or strain) }\end{array}$ & - & $\begin{array}{l}14 \\
\text { (dental) }\end{array}$ \\
\hline \multirow{2}{*}{$\begin{array}{l}\text { Messina } \\
\text { et al. [18] }\end{array}$} & 973 (boys) & 543 & - & 2 & 20 & 3 & 5 & - & 9 & - & 47 & - & 14 \\
\hline & 890 (girls) & 436 & - & 2 & 15 & 2 & 6 & - & 2 & - & 56 & - & 17 \\
\hline $\begin{array}{l}\text { Powell and } \\
\text { Barber-Foss }\end{array}$ & - & $\begin{array}{l}1,933 \\
\text { (boys) }\end{array}$ & - & 2.8 & - & - & 8.6 & - & - & 26.6 & 44.8 & 15.1 & 2.2 \\
\hline [19] & - & $\begin{array}{c}1,748 \\
\text { (girls) }\end{array}$ & - & 3.6 & - & - & 6.8 & - & - & 22.8 & 45.1 & 17.7 & 4.0 \\
\hline NATA & ? boys & $?$ & - & - & 22 & - & - & - & - & - & 43 & - & 65 \\
\hline $\begin{array}{l}(1986-1988) \\
{[41]}\end{array}$ & ? girls & $?$ & - & - & 18 & - & - & - & - & - & 41 & - & 41 \\
\hline NATA & ? boys & ? & - & - & 26.5 & - & _- & - & - & - & 44.6 & 13.3 & 15.6 \\
\hline $\begin{array}{l}(1995-1997) \\
{[41]}\end{array}$ & ? girls & $?$ & - & - & 19.6 & - & - & - & - & - & 44.2 & 16.2 & 20 \\
\hline \multicolumn{14}{|c|}{ Clubs/Sports organizations } \\
\hline Gutgesell [23] & 406 (boys) & 39 & - & - & 35.9 & - & 2.6 & - & 5.1 & - & $\begin{array}{l}28.2 \\
\text { (or strain) }\end{array}$ & - & $28.2^{*}$ \\
\hline $\begin{array}{l}\text { Yde and } \\
\text { Nielsen [25] }\end{array}$ & 56 & 21 & - & - & - & - & - & - & - & - & - & - & - \\
\hline \multirow[t]{2}{*}{ de Loës [26] } & $\begin{array}{c}15,095 \\
\text { (boys) }\end{array}$ & 243 & - & - & 14.8 & 2.5 & 13.0 & - & 3.7 & - & 65.5 & - & 3.0 \\
\hline & $\begin{array}{r}10,154 \\
\text { (girls) }\end{array}$ & 229 & - & - & 14.8 & 4.8 & 13.0 & - & 2.2 & - & 64.6 & - & 0.6 \\
\hline $\begin{array}{l}\text { Hickey } \\
\text { et al. [27] }\end{array}$ & $\begin{array}{l}49 \\
\text { (girls) }\end{array}$ & $223^{\mathrm{a}}$ & - & - & - & - & 9.3 & 10.3 & - & 6.3 & 21.9 & - & 3.6 \\
\hline
\end{tabular}


Table 3 (continued)

\begin{tabular}{|c|c|c|c|c|c|c|c|c|c|c|c|c|c|}
\hline Study & $\begin{array}{l}\text { Number of } \\
\text { participants }\end{array}$ & $\begin{array}{l}\text { Number } \\
\text { of injuries }\end{array}$ & Abrasions & $\begin{array}{l}\text { Concussions/ } \\
\text { Neuro }\end{array}$ & $\begin{array}{l}\text { Contu- } \\
\text { sion }\end{array}$ & $\begin{array}{l}\text { Luxa- } \\
\text { tions }\end{array}$ & $\begin{array}{l}\text { Frac- } \\
\text { tures }\end{array}$ & $\begin{array}{l}\text { Inflamma- } \\
\text { tion }\end{array}$ & $\begin{array}{l}\text { Lacera- } \\
\text { tions }\end{array}$ & $\begin{array}{l}\text { Nonspe- } \\
\text { cific }\end{array}$ & Sprain & Strain & $\begin{array}{l}\text { Other/ } \\
\text { Unknown }\end{array}$ \\
\hline \multicolumn{14}{|c|}{ Emergency departments } \\
\hline $\begin{array}{c}\text { Taylor and } \\
\text { Attia [12] }\end{array}$ & - & 132 & $\begin{array}{l}13.6 \% \\
\text { (or contusion) }\end{array}$ & - & - & - & 28 & - & 5.3 & - & 48.5 & ${ }^{-}$ & 4.5 \\
\hline $\begin{array}{l}\text { Damore } \\
\text { et al. [29] }\end{array}$ & $\begin{array}{l}108 \\
\text { (patients) }\end{array}$ & 111 & 1 & - & 19 & 5 & 28 & - & - & 1 & 47 & - & - \\
\hline \multicolumn{14}{|c|}{ Belechri et al. [42] } \\
\hline$(\mathrm{DEN})$ & $?$ & 257 & 33.9 & 0.8 & $\begin{array}{l}\text { (see } \\
\text { abrasion) }\end{array}$ & 38.9 & 19.5 & - & 1.9 & 5 & $\begin{array}{l}\text { (see } \\
\text { luxations) }\end{array}$ & - & - \\
\hline (FRA) & $?$ & 100 & 55 & 0.0 & $\begin{array}{l}\text { (see } \\
\text { abrasion) }\end{array}$ & 24 & 17 & - & 3 & 1 & $\begin{array}{l}\text { (see } \\
\text { luxations) }\end{array}$ & - & - \\
\hline (GRE) & $?$ & 856 & 49.5 & 1.2 & $\begin{array}{l}\text { (see } \\
\text { abrasion) }\end{array}$ & 21.7 & 20.9 & - & 4 & 2.7 & $\begin{array}{l}\text { (see } \\
\text { luxations) }\end{array}$ & - & - \\
\hline (NED) & $?$ & $2,000 * *$ & 39 & 0.0 & $\begin{array}{l}\text { (see } \\
\text { abrasion) }\end{array}$ & 20 & 36 & - & 1 & 5 & $\begin{array}{l}\text { (see } \\
\text { luxations) }\end{array}$ & - & - \\
\hline (UK) & $?$ & $3,242 * *$ & 17.4 & 0.5 & $\begin{array}{l}\text { (see } \\
\text { abrasion) }\end{array}$ & 20.3 & 20.7 & - & 5.3 & 35.8 & $\begin{array}{l}\text { (see } \\
\text { luxations) }\end{array}$ & - & - \\
\hline $\begin{array}{l}\text { Finch } \\
\text { et al. [43] }\end{array}$ & 3,308 & 3,722 & 2.1 & - & 15.4 & - & 26.1 & 9.9 & 4.3 & - & $\begin{array}{l}33.3 \\
\text { (or strain) }\end{array}$ & - & 8.8 \\
\hline
\end{tabular}

*Includes $12.8 \%$ epistaxis.

aPercentages for most common injuries only.

**Extrapolated to nationwide estimate. 


\section{Catastrophic Injury}

Death or significant permanent disability is a powerful specter for parents and coaches of young basketball players. Fortunately, the risk of such events is small. Catastrophic injuries principally involve three body systems: central nervous system, cardiovascular system and respiratory system. In addition, significant permanent damage has been recorded for injuries to the eyes.

Although most brain and spine injuries occur from falling or colliding with fixed objects, other factors can be involved. For example, Tudor [51] describes a 17-year-old male player struck on the side of the head from a ball rebounding off the rim, producing an acute subdural hematoma with permanent disability including visual, emotional and behavioral deficits.

The most comprehensive picture of catastrophic injuries in pediatric basketball comes from the National Center for Catastrophic Sports Injuries (NCCSI) [52] which has been tracking these incidents in high school basketball programs in the USA since 1982. According to NCCSI, a catastrophic injury may be direct (brain/spinal cord injury or skull/spinal fracture) or indirect (systemic failure as a result of exertion in basketball or by a complication secondary to a non-fatal injury). In its 21st Annual report, NCCSI found that, in the period 1982-2003, there were 16 direct catastrophic injuries in this population, consisting of 2 fatalities (both male); 4 nonfatalities (permanent severe functional disability) and 10 serious injuries (no permanent disability but significant initial injuries, for example, vertebral fracture without paralysis). The direct injury fatality rate for males was 0.02 per 100,000 participants. For direct nonfatal injuries, the rate was 0.3 per 100,000 for males and 0.01 for females. For serious catastrophic injuries, the rate was 0.07 for males and 0.02 for females. However, there were 92 indirect catastrophic injuries during the same time producing 90 fatalities for a rate of 0.82 per 100,000 for males and 0.10 per 100,000 for females. Typically, indirect fatalities are cardiac failures [53]. No nonfatal injuries were recorded but the rate of indirect serious injuries was 0.01 per 100,000 for both males and females. The data in this report supercede several previous studies [53-55] but it is difficult to determine whether it captures all catastrophic injuries in high school-aged players. For example, those who may be injured in clubs.

Maron et al. [56] analyzed 134 cases of cardiovascular-related sudden deaths in trained athletes from 1985-1995: basketball accounted for 35\%. The median age of fatalities was 17 (range 12-40), with 90\% male. Hypertrophic cardiomyopathy was disproportionately prevalent in black athletes (48 vs. $26 \%$ of deaths; $\mathrm{p}=0.01$ ). Additional case reports indicate a variety of causal mechanisms. Serdaroglu et al. [57] commented on the case of a 15-year-old player who fell and developed multiple sensory and motor deficits. His condition deteriorated before a rupture of the descending aorta was diagnosed and treated surgically but 
without success. Messina et al. [18] implicated pulmonary 'complications' subsequent to a thigh contusion in the death of a 16-year-old male player.

The most important respiratory complication appears to be related to asthma. A recent 7-year study of asthma-related fatalities in sport [58] found that of 61 deaths most occurred in athletes aged under 20 (prevalent group 10-14), with basketball one of the two most frequent activities precipitating a fatal episode (track was the other).

Finally, a series of case reports indicate that significant and permanent damage to the eyes can arise from fingers or the ball penetrating the orbit. Of particular concern are avulsions of the optic nerve, at least 7 cases of which are reported in the literature $[59,60]$.

\section{Time Loss}

If advances in playing safety are to occur, understanding the circumstances of injuries that result in time away from playing or normal life activities, such as school, is critical. A summary of time-loss studies is shown in table 4 [15, 20, $23,25,28,31,33,41,48,61-63]$. Unfortunately, the variety of data sources (clubs, schools, hospitals), player attributes (gender, age) and sociocultural characteristics (nationality, urban) make it difficult to get a clear picture of the risk of significant (i.e., time loss) injuries in pediatric basketball. Moreover, actual time-loss data are provided in only a limited number of studies although some information on time loss can be extrapolated from injury-severity data.

For example, Gutgesell [23] noted that only $2.4 \%$ of injuries in a YMCA program with children aged 5-12 resulted in missed playing time but did not provide any further details. In a study in a Danish sports club involving players up to the age of $18,43 \%$ of time-loss injuries were resolved in less than 2 weeks with a further $33 \%$ resolved by 4 weeks. No case took longer than 6 weeks to resolve [25].

In an early high school study, McLain and Reynolds [15] found that the mean time lost for a basketball injury for boys was 11.8 days but 28.6 days for girls. However, the authors noted that there were only 45 girls in the study, and one sustained an ACL rupture necessitating surgical reconstruction and was absent for almost a full year. Removing this case from the data brought the girls' average time-loss due to injury to 7.8 days. The influence of a single significant injury on outcomes such as the mean days lost when the pool is small is problematic. Similarly, Axe et al. [61] undertook a 1-year prospective study of adolescent sports injuries reporting to a Delaware sports clinic: female basketball players averaged 12.8 days lost per injury ( 28 cases with 3 surgeries) compared to 9.2 days for boys (20 cases with one surgery). As above, one female case was a season-ending ACL rupture (110 days lost) and removing this from the tally reduced average days lost for girls to 8.8 . 
Table 4. Summary of injury-related time loss in youth basketball

\begin{tabular}{|c|c|c|c|c|}
\hline Study & $\begin{array}{l}\text { Number of } \\
\text { injuries }\end{array}$ & Age & Situation & Time loss \\
\hline McLain and Reynolds [15] & $\begin{array}{l}21 \text { (boys) } \\
14 \text { (oirls) }\end{array}$ & $15-18$ & High school & $\begin{array}{l}\text { Boys: } 11.8 \text { days (mean); } \\
\text { Girls } 28 \text { davs (mean) (w/o } 1 \text { ACL case oirls' mean. } 78 \text { davs) }\end{array}$ \\
\hline Beachey et al. [20] & $\begin{array}{l}505 \text { (boys) } \\
467 \text { (girls) }\end{array}$ & $\begin{array}{c}\text { Grades } \\
7-12\end{array}$ & High school & $\begin{array}{l}\text { Boys: } 31 \%>1 \text { day } \\
\text { Girls: } 37 \%>1 \text { day }\end{array}$ \\
\hline Gutgesell [23] & 39 (boys/girls) & $5-12$ & YMCA & $2.4 \%$ missed playing time \\
\hline Yde and Nielsen [25] & 21 (boys/girls) & $<18$ & Club & $43 \%<2$ weeks; $33 \%$ 2-4 weeks; $24 \%$ 4-6 weeks \\
\hline Prebble et al. [28] & 1,210 & $\begin{array}{l}77.8 \% \\
10-19\end{array}$ & ED (USA) & $71.2 \%<14$ days \\
\hline $\begin{array}{l}\text { McGuine et al. [31] } \\
\text { (ankle only) }\end{array}$ & 23 (boys/girls) & $15-18$ & High school & $\begin{array}{l}56.5 \%<7 \text { days; } 39.1 \% 7-21 \text { days; } 4.3 \%>21 \text { days; } \\
7.1 \text { days (mean) }\end{array}$ \\
\hline $\begin{array}{l}\text { Powell and Barber-Foss [33] } \\
\text { (MTBI only) }\end{array}$ & 1,219 & $15-18$ & High school & $\begin{array}{l}\text { Boys: } 88.2 \%<8 \text { days; } 9.8 \% 8-21 \text { days; } 2.0 \%>21 \text { days } \\
\text { Girls: } 83.1 \%<8 \text { days; } 13.8 \% 8-21 \text { days; } 3.1 \%>21 \text { days }\end{array}$ \\
\hline NATA [41] & $?$ & $15-18$ & High school & $\begin{array}{l}\text { Boys: } 79.4 \%<7 \text { days; } 12.4 \% 7-21 \text { days; } 8.2 \%>21 \text { days } \\
\text { Girls: } 76 \%<7 \text { days; } 15 \% 7-21 \text { days; } 9.0 \%>21 \text { days }\end{array}$ \\
\hline Sorenson et al. [48] & 57 (boys) & $\begin{array}{l}6-17 \\
6-17\end{array}$ & $\mathrm{ED}(\mathrm{DEN})$ & $\begin{array}{l}\text { Boys: mean } 5.4 \text { days (range } 0-45 \text { days) from training } \\
\text { Boys: mean } 1.5 \text { days (range } 0-20 \text { days) from school } \\
\text { Girls: mean } 4.2 \text { days (range } 0-40 \text { days) from training } \\
\text { Girls: mean } 0.3 \text { days (range } 0-5 \text { days) from school }\end{array}$ \\
\hline Axe et al. [61] & $\begin{array}{l}20 \text { (boys) } \\
28 \text { (girls) }\end{array}$ & $14-18$ & Clinic & $\begin{array}{l}\text { Boys: } 9.2 \text { days (mean); Girls: } 12.8 \text { days (mean) } \\
\text { (w/o 1 ACL case, girls' mean: } 8.8 \text { days) }\end{array}$ \\
\hline Rider and Hicks [62] & 52 (boys/girls) & $15-18$ & High school & $96 \%<7$ days; mean $=3.1$ days \\
\hline Watson [63] & 9 & $10-18$ & Elementary/HS & $\begin{array}{l}\text { BB }>\text { than mean for all sports for hospitalization } \\
(0.47 \text { days; } 18 \text { days out })\end{array}$ \\
\hline
\end{tabular}


Data from several other high school studies provide a mixed picture. Rider and Hicks [62] found that, in a study of male and female high school varsity players over one season, $27 \%$ missed at least one day due to injury but only $4 \%$ missed more than 7 days. The average for the group was 3.1 days. Beachey et al. [20] noted that, over an 8-year period, $31 \%$ of injuries to boys in a single high school team resulted in at least one day lost from practice, while about $37 \%$ of injuries to girls were time-loss, although no information on average time-loss or the range was provided. In a 3-year study involving a national sample of high schools, the National Athletic Trainers Association (NATA) [41] found that $79.4 \%$ of boys' injuries and $76 \%$ of girls' injuries could be considered minor ( $<7$ days absent) with only $8.2 \%$ for boys and $9.0 \%$ for girls being major (requiring more than 21 days).

However, in a one-year study of Irish school children aged 10-18, Watson [63] found that, while basketball accounted for only $7.7 \%$ of the injuries recorded ( 9 of 116), these 'tended to result in an above average period of hospitalization and incapacity' (average period of hospitalization for all sports was 0.47 days with 18 days of incapacity). The author suggests that the difference with American data may be sociocultural in that 'Irish teachers and coaches are reluctant to classify an incident as an 'injury' unless the level of incapacity is high and they tend to ignore conditions that would be referred for medical treatment in America, where the level of involvement of medical and paramedical personnel in sport is considerably greater' $(p 70)$.

School-based studies of the severity of particular types of injuries have also been published. Powell and Barber-Foss [33] examined MTBI in male and female athletes in 235 USA high schools and found that $5.5 \%$ of all reported injuries in 10 sports over 3 years were MTBI with boys and girls basketball accounting for $4.2 \%$ (51 cases) and $5.2 \%$ (63 cases) of the total, respectively. Most cases were minor (resolved in $<8$ days) in 88.2 and $83.1 \%$ of cases for boys and girls, respectively, with only 2 and $3.1 \%$, respectively, taking more than 21 days. In a prospective study investigating balance characteristics on the risk of ankle injury, McGuine et al. [31] found that 56.5\% of reported ankle injuries in the study group of 210 male and female athletes resolved in less than 7 days while $39.1 \%$ took $7-21$ days. Only one injury (4.3\%) took longer than 21 days to resolve.

Finally, information from several hospital-based studies, which theoretically should involve more severe cases, indicates that the bulk of basketball injuries are minor. Finch et al. [43] found that, although basketball was the fourth leading cause of sports-related injuries in a 4-year national study of emergency departments, it ranked ninth (of ten) in subsequent hospital admissions. In a study in rural America, Prebble et al. [28] found that $71.2 \%$ of cases seen at an emergency department resolved in less than 2 weeks. In contrast, a more 
extensive study from Denmark [48] found that basketball injuries resulted in an average time away from training of 5.4 days (range 0-45 days) for boys and 4.2 days (range $0-40$ ) for girls. However, the time absent from school was only 1.5 days (range $0-20$ ) for boys and 0.3 days (range $0-5$ days) for girls, indicating that the limitations were activity-specific rather than generally debilitating.

\section{Clinical Outcome}

In line with the limited amount of quality data on more direct issues related to understanding the nature and risk of basketball injuries, very little research has been performed on the associated costs of injuries, such as the financial impact (both direct and indirect) on individuals, sponsoring organizations, and national associations. Although improvements in playing safety can arise from altruistic concerns, progress tends to come from the impact of pragmatic issues such as the influence of injuries on insurance costs, days lost from work or school, or the drain on medical resources. For example, in a 7-year study of only knee injuries in a national sample of 14-20-year-old male and female players in Switzerland, de Loës et al. [30] found that the mean medical cost for treatment of knee injuries (including ACL/PCL ruptures) was USD 1,427 for males and USD 1,060 for females. These costs were in the context of a national insurance program. By contrast, Hewett et al. [64] estimated that the cost of reconstruction and rehabilitation of an ACL rupture in a female high school basketball player in the USA is at least USD 17,000, producing a total direct financial impact of more than USD 119 million per year for this population alone [65]. If only $1 \%$ of the costs were available for research on injury analysis and prevention, substantial advances could be made in reducing the human, financial, and medical burden of basketball injuries in youth and adolescent players. Similarly, Newsome et al. [66] reported that the lifetime dental costs of a tooth avulsion that is not properly preserved or replanted can be more than USD 10,000 but custom-fitted mouthguards that can reduce the risk significantly can be made available for less than USD 10 [67].

\section{Injury Risk Factors}

\section{Intrinsic Factors}

Gender

Despite the widely varying quality of the literature dealing with injuries in youth basketball, girls are more at risk than boys, particularly for knee and ankle injuries, and these injuries tend to be serious [14, 16, 18, 19, 23, 26, 30, 32, 41, $49,68]$. This relationship has been noted in club $[23,26,30]$ and scholastic studies $[14,16,32,41,49,68]$, in the USA [14, 16, 18, 32, 41, 49, 68] and 
abroad $[26,30]$. Several studies have found no overall gender difference in injury data $[18,19,25]$ but still noted significant differences in the number of knee injuries between boys and girls [18, 19].

Specifically, although several high school studies did not find a significant difference in overall injury rates between boys and girls $(p=0.11)$ [18], IDR $=1.01,95 \% \mathrm{CI}=0.95-1.08$ [19], there is a gender-related risk $(\mathrm{p}<0.05)$ [26], $(\mathrm{p}<0.02)$ [23], $(\mathrm{p}<0.001)$ [14], $(\mathrm{p}<0.0004)$ [16]. In addition, although Gutgesell [23] found a similar rate of serious injury between boys and girls, others identified a significant difference in this outcome $(p<0.05)$ [19]; $(\mathrm{p}<0.001)$ [14], with Chandy and Grana [14] noting a significantly greater number of season-ending injuries for girls $(\mathrm{p}<0.001)$.

Of the available literature, girls are at a greater risk of sustaining a knee injury $(\mathrm{p}<0.001)$ [14]; (IDR $=1.44 ; 95 \%$ CI: 1.2-1.71) [19]; (IDR 1.7, $\mathrm{p}<0.05)$ [30]; (RR 1.92, $\mathrm{p}<0.0001)$ [32]; (RR 2.29, $\mathrm{p}<0.001)$ [18], and the knee injury is more likely to require surgery $(\mathrm{p}<0.05)$ [14]; (IDR $=2.65,95 \%$ $\mathrm{CI}=1.64-4.29)[19] ;(\mathrm{p}<0.047)[18]$ and/or involve the ACL $(\mathrm{RR}=9.0$, $\mathrm{p}=0.05)[49] ;(\mathrm{RR}=3.79, \mathrm{p}<0.024)[18] ;(\mathrm{p}<0.01)$ [68]; (IDR $=4.14$, 95\% CI: 2.18-7.9) [19]. However, Piasecki et al. [49] noted that girls seem to be at less risk for medial femoral condyle injuries $(\mathrm{p}=0.05)$.

Girls also seem to be at greater risk than boys of sustaining an ankle injury $(\mathrm{RR}=1.24, \mathrm{p}<0.05)[32]$ and being reinjured $(\mathrm{p}=0.002)[19]$.

Age and Development

There is conflicting information about the influence of age and/or level of development on injury in young players. Yde and Nielsen [25] concluded that the risk of injury increases with age, while DuRant et al. [16] did not. However, Michaud et al. [11] reported that the risk appears to increase with pubertal development (Tanner stage 4 or 5) rather than chronological age. A study of five European Union nations [42] showed a consistent increase in the percentage of basketball injuries with age. Although this may be simply a reflection of increasing participation rates, it probably also captures the influence of physical development on injuries as players become larger, stronger and faster. The percentage of all basketball injuries represented by 5-8 year olds ranged from $1 \%$ in France to $5.4 \%$ in the United Kingdom; for those $9-10$ from $4 \%$ in France to $16 \%$ in Greece; $11-12$ from $23 \%$ in France to $39.3 \%$ in Denmark; and for $13-14$ year olds from $42.9 \%$ in Greece to $72 \%$ in France.

Psychological Characteristics

Despite the importance of psychological factors on performance, few studies have examined the relationship between mental states and injury. Only two studies dealt with these issues in young basketball players. In a study 
conducted in the late 1970s with female high school players, Young and Cohen [69] found that injured players were significantly different from uninjured players on several psychological measures, including total self-concept, selfcriticism, and in measures of external frames of reference, indicating they may be inherently 'risk-takers'. In a more recent study no relationship was found between psychological factors related to life-stress events, coping skills and social support and time-loss due to injury [62].

\section{Other Factors}

As the effort to reduce injury rates in youth basketball continues, researchers have focused on a diverse range of potential risk factors, including proprioceptive ability [31], level of motor development [39], level of competition [32], and influence of fixed orthodontic appliances [35].

McGuine et al. [31] examined the relationship between a standardized balance test and ankle injury, and found a positive linear relationship between postural sway (measured in degrees per second) and rate of ankle injuries per 1,000 AE. Kelm et al. [39] reported that more than $50 \%$ of all basketball injuries in physical education classes involving 11-15 year olds involved catching, implicating poor motor skills, including hand/eye coordination, as a risk factor.

In a 2-year prospective study with matched boys and girls high school and college programs, Hosea et al. [32] found that the relative risk of injury increased with level of competition (from high school to college), doubling for both boys and girls. However, for ACL injuries specifically, the relative risk was significant for girls $(3.66: 1 ; \mathrm{p}<0.01)$ but not boys moving to collegiate competition.

Finally, Kvettem et al. [35] noted a relative risk of orofacial injury while wearing a fixed orthodontic appliance of $1.7(95 \% \mathrm{CI}=1.1-2.5)$, although the small sample warrants caution in interpreting the data.

\section{Extrinsic Factors}

Few studies have attempted to identify play-related factors that impact injury potential. Data from two studies $[33,50]$ indicate that playing guard is more hazardous than playing forward. In a report of knee injuries in 22 female high school basketball programs in Iowa, guards had 3 times as many knee ligament tears as forwards [50]. In addition, guards were most at risk for gamerelated MTBI (62.5\% boys; $56.4 \%$ girls), although forwards accounted for most MTBI injuries in practice (68.4\% boys; $62.5 \%$ girls) [33].

Addressing a common situation in community-based programs, Gutgesell [23] found that for young children playing on a linoleum-tile playing surface was not more hazardous than playing on a standard wood floor. 


\section{Suggestions for Injury Prevention}

Despite the dearth of definitive information on risk factors related to youth basketball, a variety of recommendations have been presented based on the limited research and general observations and which take into account the unique characteristics of young players. A summary of the recommendations indicating the study design of the resources from which the recommendations were drawn is shown in table $5[14,16,19,22,25,31,34-36,39,40,46,59$, $60,63-67,70-73]$. The majority are 'common sense' responses to apparent cause-effect relationships and cover multiple aspects of playing basketball. Although few have been empirically tested, the general principle on which they are based, i.e., modifying the rigors of the game and/or the physical capacities of the players to better match, is not unreasonable and has some research support. A summary of prevention studies is shown in table $6[31,62,64,69$, 71, 72, 74-76].

Injury prevention studies are predictive or remedial. On the premise that it is better to prevent than correct an injury, identifying predictive characteristics should be a primary research goal. Studies, covering physical (balance, structural symmetry, tenderness) and psychological (self-concept, coping skills) factors, have had mixed success. However, because of methodological problems, including limited sample sizes, it is unclear whether factors that found to have no predictive value in fact are not related to injury, or whether the relationship is masked by design flaws. In some cases, implementation of predictive or screening protocols is hampered by logistical issues such as cost and the need for specialized equipment. Hewett et al.'s [64] remedial intervention program of neuromuscular training to reduce the incidence of knee injuries is the most promising as it is designed to complement normal basketball conditioning programs.

\section{Suggestions for Further Research}

The lack of clear comprehensive data on injuries in youth basketball is distressing considering that it is one of the most popular sports in the world and the number of young participants is rising, as is the personal, financial and social burden of basketball injuries. The options for future research are numerous, and fall into three broad categories: (1) development of appropriate research programs in general, (2) research into specific risk factors, and (3) research into the characteristics of specific injuries.

If any significant progress is to be made in understanding the determinants of injury in this population, a fundamental retooling of the structure of the 
Table 5. Suggestions for injury prevention

\begin{tabular}{|c|c|c|}
\hline Preventive measure & Reference & Type of evidence \\
\hline \multicolumn{3}{|l|}{ Environmental issues } \\
\hline \multirow[t]{2}{*}{ Develop basic motor skills in new/young players } & Yde and Nielsen [25] & Prospective cohort \\
\hline & Watson [63] & Prospective cohort \\
\hline \multirow{2}{*}{$\begin{array}{l}\text { Modify playing conditions to players' skill level } \\
\text { (court and ball size, number of players, etc) }\end{array}$} & Yde and Nielsen [25] & Prospective cohort \\
\hline & Kelm et al. [39] & Case series \\
\hline $\begin{array}{l}\text { Reduce size of physical education classes for better } \\
\text { instruction/supervision }\end{array}$ & Backx et al. [22] & Prospective cohort \\
\hline \multirow{2}{*}{ Ensure well-trained officials } & DuRant et al. [16] & Prospective cohort \\
\hline & Watson [63] & Prospective cohort \\
\hline Ensure players matched in physical characteristics/skill & DuRant et al. [16] & Prospective cohort \\
\hline \multicolumn{3}{|l|}{ Protective equipment and conditions } \\
\hline \multirow[t]{8}{*}{ Educate parents, coaches, players about mouth guard use* } & $\begin{array}{l}\text { Maestrello-deMoya and } \\
\text { Primosch [34] }\end{array}$ & Retrospective cohort \\
\hline & Kvettem et al. [35] & Prospective cohort \\
\hline & Teo et al. [36] & Retrospective cohort \\
\hline & Diab and Mourino [46] & Cross-sectional \\
\hline & Newsome et al. [66] & Review \\
\hline & McNutt et al. [70] & Cross-sectional \\
\hline & Foster and March [71] & Quasi-experimental field study \\
\hline & Jalleh et al. [72] & Quasi-experimental field study \\
\hline Develop methods to supply inexpensive custom mouthguard** & Johnson and Parker [67] & Implementation project \\
\hline Campaign for mandatory mouthguard use & Foster and March [71] & Quasi-experimental field study \\
\hline Encourage voluntary mouthguard use & Teo et al. [36] & Retrospective cohort \\
\hline \multirow{2}{*}{ Encourage use of protective eyewear } & Chow et al. [59] & Case study \\
\hline & Friedman $[60]$ & Case study \\
\hline
\end{tabular}


Table 5 (continued)

\section{d)}

Ensure coaches have first aid training

Ensure that high schools have NATA-certified athletic trainers

Engage injured athletes in well constructed rehabilitation programs

Player attributes

Implement developmentally appropriate preparticipation fitness evaluations

Implement developmentally appropriate conditioning programs (strength, agility, flexibility, power)

Instigate specific ankle stabilization/proprioception training

Instigate specific ACL dynamic neuromuscular training*** (especially for girls)

\begin{tabular}{|c|c|}
\hline Reference & Type of evidence \\
\hline Backx et al. [40] & Prospective cohort \\
\hline AAFP [73] & Policy statement \\
\hline McGuine et al. [31] & Prospective cohort \\
\hline Chandy and Grana [14] & Retrospective cohort \\
\hline Chandy and Grana [14] & Retrospective cohort \\
\hline DuRant et al. [16] & Prospective cohort \\
\hline Backx et al. [22] & Prospective cohort \\
\hline Watson [63] & Prospective cohort \\
\hline Powell and Barber-Foss [19] & Retrospective cohort \\
\hline Backx et al. [22] & Prospective cohort \\
\hline Hewett et al. [64] & Prospective cohort \\
\hline Ford et al. [65] & Laboratory study \\
\hline
\end{tabular}

*A complete team and community educational program is available from Sports Medicine Australia (Western Australia Branch). This program has been demonstrated to be effective in significantly increasing mouthguard use in young basketball players. For further details refer to Foster and March [71] and Jalleh et al. [72].

**Refer to Johnson and Parker [67] for a description of a project that supplied custom-fitted mouthguards to three high school teams for under $\$ 10$ each.

***Refer to Hewett et al. [64] for a description of a program shown to significantly reduce the incidence of serious knee injuries. 
Table 6. Summary of injury prevention studies

\begin{tabular}{|c|c|c|c|c|c|}
\hline Reference & Design & Participants & Intervention & $\begin{array}{l}\text { Outcome } \\
\text { variable }\end{array}$ & Results \\
\hline McGuine et al. [31] & $\begin{array}{l}\text { Prospective } \\
\text { cohort }\end{array}$ & $\begin{array}{l}\text { High school } \\
(\mathrm{n}=210)\end{array}$ & $\begin{array}{l}\text { Postural sway } \\
\text { measures }\end{array}$ & Ankle injuries & $\begin{array}{l}\text { Athletes with high sway scores } 7 \text { times } \\
\text { risk of ankle injury }(\mathrm{p}=0.0002)\end{array}$ \\
\hline Rider and Hicks [62] & $\begin{array}{l}\text { Prospective } \\
\text { cohort }\end{array}$ & $\begin{array}{l}\text { High school } \\
(\mathrm{n}=67)\end{array}$ & $\begin{array}{l}\text { Psychological } \\
\text { measures of life } \\
\text { events stress, coping } \\
\text { skills, social support }\end{array}$ & Injury & $\begin{array}{l}\text { No predictive value in these } \\
\text { measures }\end{array}$ \\
\hline Hewett et al. [64] & $\begin{array}{l}\text { Nonrandomized } \\
\text { clinical trial }\end{array}$ & $\begin{array}{l}\text { High school } \\
(\mathrm{n}=498)\end{array}$ & $\begin{array}{l}\text { Jump training, } \\
\text { stretching, } \\
\text { weight training }\end{array}$ & $\begin{array}{l}\text { Serious knee } \\
\text { injuries }\end{array}$ & $\begin{array}{l}\text { Trained: fewer noncontact } \\
\text { knee injuries }(p=0.019)\end{array}$ \\
\hline $\begin{array}{l}\text { Young and } \\
\text { Cohen [69] }\end{array}$ & $\begin{array}{l}\text { Prospective } \\
\text { cohort }\end{array}$ & $\begin{array}{l}\text { High school } \\
(\mathrm{n}=190)\end{array}$ & $\begin{array}{l}\text { Psychological } \\
\text { measures of } \\
\text { self-concept }\end{array}$ & Injury & $\begin{array}{l}\text { Total self-concept, self-criticism, } \\
\text { identity, personal self } \& \text { physical } \\
\text { scale scores significantly different } \\
\text { between injured and non-injured } \\
\text { players }(\mathrm{p}<0.1)\end{array}$ \\
\hline $\begin{array}{l}\text { Foster and } \\
\text { March [71] } \\
\text { Jalleh et al. [72] }\end{array}$ & $\begin{array}{l}\text { Quasi- } \\
\text { experimental } \\
\text { field study }\end{array}$ & $\begin{array}{l}\text { Club (pre: } \\
\mathrm{n}=1,429 \text { ) } \\
\text { (post: } \\
\mathrm{n}=1,148 \text { ) }\end{array}$ & $\begin{array}{l}\text { Mouthguard } \\
\text { education } \\
\text { program }\end{array}$ & $\begin{array}{l}\text { Mouthguard } \\
\text { use }\end{array}$ & $\begin{array}{l}\text { Use increased significantly - } \\
\text { Competition: } \\
\text { OR = } 2.55 \text { (95\% CI: } 2.04-3.18) \\
\text { Training: } \\
\text { OR = } 4.39 \text { (95\% CI: } 3.21-6.00)\end{array}$ \\
\hline Grubbs et al. [74] & $\begin{array}{l}\text { Nonrandomized } \\
\text { clinical trial }\end{array}$ & $\begin{array}{l}\text { High school } \\
(\mathrm{n}=62)\end{array}$ & $\begin{array}{l}\text { Structural symmetry } \\
\text { measures }\end{array}$ & $\begin{array}{l}\text { Lower extremity } \\
\text { injuries }\end{array}$ & $\begin{array}{l}\text { No predictive value in these } \\
\text { measures }\end{array}$ \\
\hline Cook et al. [75] & $\begin{array}{l}\text { Prospective } \\
\text { cohort }\end{array}$ & Club $(n=26)$ & $\begin{array}{l}\text { Ultrasonography of } \\
\text { patellar tendon }\end{array}$ & $\begin{array}{l}\text { Patellar } \\
\text { symptoms }\end{array}$ & $\begin{array}{l}\text { Ultrasonographic hypoechoic area } \\
\text { associated with patellar tendinitis } \\
(\mathrm{p}<0.05) \text { but baseline values not } \\
\text { predictive of outcome }\end{array}$ \\
\hline Cook et al. [76] & Correlational & Club $(\mathrm{n}=163)$ & $\begin{array}{l}\text { Palpation of patellar } \\
\text { tendon }\end{array}$ & $\begin{array}{l}\text { Patellar } \\
\text { tendinitis }\end{array}$ & $\begin{array}{l}\text { Patellar tenderness is not a useful } \\
\text { in preparticipation examinations as } \\
\text { screening method }\end{array}$ \\
\hline
\end{tabular}


research, utilizing appropriate epidemiological methods, is necessary. A number of authors have commented on such basic considerations as the need to establish standards for an unambiguous definition of reportable injury and denominator data (exposure information), and the use of trained professionals, such as certified athletic trainers with standardized recording systems, to develop the data for analysis $[19,25,26]$, within a coordinated series of regional and national databases [68].

Identifying risk and protective factors associated with the diverse characteristics of the pediatric population remains a high priority. Issues such as age, level of competition, developmental status, and the influence of various types of training programs or psychological and social factors on injury characteristics remain to be explored $[18,62]$, as does the need to establish standardized protocols for measuring intrinsic characteristics, such as postural sway, as predictors of injury [31].

Of the specific types of injuries that can occur in basketball, clearly research to reduce the incidence of knee and ankle injuries must be a high priority [27]. This is of particular importance for young female participants in light of the consistent indications of their vulnerability to these injuries. Additionally, several authors have indicated the need to continue research on orofacial injuries and mouthguard protection [34, 35], which has already yielded important advances in significantly reducing these problems.

Finally, there is a need to acknowledge basketball as a global phenomenon and that the determinants of safe play may be moderated by cultural considerations. Regional interests must be addressed in the study of short- and long-term consequences of basketball injuries in young athletes [9].

\section{References}

1 Fédération Internationale de Basketball (FIBA): Quick facts. 2004;www.fiba.com

2 National Federation of State High School Associations (NFHS): Participation sets record for sixth straight year. Press release Aug 24, 2004;www.nfhs.org

3 MMWR: Nonfatal sports- and recreation-related injuries treated in emergency departments United States, July 2000 - June 2001. MMWR 2002;51:736-740.

4 American Academy of Orthopaedic Surgeons: A guide to safety for young athletes 2002; www.orthoinfo.aaos.org/brochure.

5 National SAFE KIDS Campaign (NSKC): Sports injury fact sheet 2004. Washington DC, NSKC, 2004.

6 Zvijac J, Thompson W: Basketball; in Caine DJ, Caine CG, Lindner KJ (eds): Epidemiology of Sports Injuries. Champaign, Human Kinetics, 1996.

7 Watkins J, Peabody P: Sports injuries in children and adolescents at a sports injury clinic. J Sports Med Phys Fitness 1996;36:43-48.

8 Boyce SH, Quigley MA: An audit of sports injuries in children attending an Accident \& Emergency department. Scott Med J 2003;48:88-90. 
9 Maffulli N, Bundoc RC, Chan KM, Cheng JCY: Paediatric sports injuries in Hong Kong: A seven year survey. Br J Sports Med 1996;30:218-221.

10 Frontera WR, Micheo WF, Amy E, Melédez E, Aguirre G, Correa JJ, Camunas JF: Patterns of injury in athletes evaluated in an interdisciplinary clinic. PR Health Sci J 1994;13:165-170.

11 Michaud P-A, Renaud A, Narring F: Sports activities related to injuries? A survey among 9-19 year olds in Switzerland. Inj Prev 2001;7:41-45.

12 Taylor B, Attia MW: Sports-related injuries in children. Acad Emerg Med 2000;7:1366-1382.

13 Gordis L: Epidemiology. Philadelphia, Saunders, 2000.

14 Chandy TA, Grana WA: Secondary school athletic injuries in boys and girls: A three-year comparison. Phys Sportsmed 1985;13:106-111.

15 McLain LG, Reynolds S: Sports injuries in a high school. Pediatrics 1989;84:446-450.

16 DuRant RH, Pendergrast RA, Seymore C, Gaillard G, Donner J: Findings from the Preparticipation Athletic Examination and athletic injuries. Am J Dis Child 1992;146:85-91.

17 Gomez E, DeLee JC, Farney WC: Incidence of injury in Texas girls' high school basketball. Am J Sports Med 1996;24:684-687.

18 Messina DF, Farney WC, DeLee JC: The incidence of injury in Texas high school basketball. A prospective study among male and female athletes. Am J Sports Med 1999;27:294-299.

19 Powell JW, Barber-Foss KD: Sex-related injury patterns among selected high school sports. Am J Sports Med 2000;28:385-391.

20 Beachy G, Akau CK, Martinson M, Olderr TF: A longitudinal study at Punahou School: 1988 to 1996. Am J Sports Med 1997;25:675-681.

21 Weir MA, Watson AWS: A twelve month study of sports injuries in one Irish school. Ir J Med Sci 1996;165:165-169.

22 Backx FJ, Beijer HJ, Bol E, Erich WB: Injuries in high-risk persons and high-risk sports - A longitudinal study of 18118 school children. Am J Sports Med 1991;19:124-130.

23 Gutgesell ME: Safety of a preadolescent basketball program. Am J Dis Child 1991;145:1023-1025.

24 Chambers RB: Orthopaedic injuries in athletes (ages 6 to 17). Am J Sports Med 1979;7:195-197.

25 Yde J, Nielsen AB: Sports injuries in adolescents' ball games: Soccer, handball and basketball. Br J Sports Med 1990;24:51-54.

26 de Loës M: Epidemiology of sports injuries in the Swiss Organization 'Youth and Sports' 1987-1989. Int J Sports Med 1995;16:134-138.

27 Hickey GJ, Fricker PA, McDonald WA: Injuries to young elite basketball players over a six-year period. Clin J Sport Med 1997;7:252-256.

28 Prebble T, Chyou P-H, Wittman L, McCormick J, Collins K, Zoch T: Basketball injuries in a rural area. Wis Med J 1999;98:22-24.

29 Damore DT, Metzl JD, Ramundo M, Pan S, van Amerongen, R: Patterns in childhood sports injury. Pediatr Emerg Care 2003;19:65-67.

30 de Loës M, Dahlstedt LJ, Thomee R: A 7-year study on risks and costs of knee injuries in male and female youth participants in 12 sports. Scand J Med Sci Sports 2000;10:90-97.

31 McGuine TA, Greene JJ, Best T, Leverson G: Balance as a predictor of ankle injuries in high school basketball players. Clin J Sport Med 2000;10:239-244

32 Hosea TM, Carey CC, Harrer MF: The gender issue: Epidemiology of ankle injuries in athletes who participate in basketball. Clin Ortho Rel Res 2000;372:45-49.

33 Powell JW, Barber-Foss KD: Traumatic brain injury in high school athletes. JAMA 1999;282: 958-963.

34 Maestrello-deMoya MG, Primosch RE: Orofacial trauma and mouth-protector wear among high school varsity basketball players. J Dent Child 1989;1:36-39.

35 Kvittem B, Hardie NA, Roettger M, Conry J: Incidence of orofacial injuries in high school sport. J Public Health Dent 1998;58:288-293.

36 Teo CS, Stokes AN, Loh T, Bagramin RA: A survey of tooth injury experience and attitudes to prevention in a group of Singapore schoolboys. Ann Acad Med 1995;24:23-25.

37 Burt CW, Overpeck MD: Emergency visits for sports-related injuries. Ann Emerg Med 2001;37:301-308.

38 Conn JM, Annest JL, Gilchrist J: Sports and recreation related injury episodes in the US population, 1997-99. Inj Prev 2003;9:117-123. 
Kelm J, Ahelm F, Pape D, Pitsch W, Engel C: School sports accidents: Analysis of causes, modes, and frequencies. J Pediatr Orthop 2001;21:165-168.

40 Backx FJ, Erich WB, Kemper AB, Verbeek AL: Sports injuries in school-aged children - An epidemiological study. Am J Sports Med 1989;17:234-240.

41 National Athletic Trainers Association (NATA): 1995-1997 injury surveillance overview. NATA 2004;www.nata.org/publications/otherpubs/injuryinformaiton.htm

42 Belechri M, Petridou E, Kedikolglou S, Trichopoulos D, 'Sports Injuries' European Union Group: Sports injuries among children in six European Union countries. Eur J Epidemiol 2001;17: 1005-1012.

43 Finch C, Valuri G, Ozanne-Smith J: Sport and active recreation injuries in Australia: Evidence from emergency department presentations. Br J Sports Med 1998;32:220-225.

44 Macgregor DM: Don’t save the ball. Br J Sports Med 2003;37:351-353.

45 Sane J: Comparison of maxillofacial and dental injuries in four contact team sports: American football, bandy, basketball, and handball. Am J Sports Med 1988;16:647-652.

46 Diab N, Mourino AP: Parental attitudes towards mouthguards. Pediatr Dent 1997;19:455-460.

47 Wan J, Corvino TF, Greenfield SP, DiScala C: Kidney and testicle injuries in team and individual sports: Data from the National Pediatric Trauma Registry. J Urol 2003;170:1528-1532.

48 Sorenson L, Larsen SE, Rock ND: Sports injuries in school-aged children - A study of traumatological and socioeconomic outcome. Scand J Med Sci Sports 1998;8:52-56.

49 Piasecki DP, Spindler KP, Warren TA, Andrish JT, Parker RD: Intraarticular injuries associated with anterior cruciate ligament tear: Findings at ligament reconstruction in high school and recreational athletes. Am J Sports Med 2003;31:601-605.

50 Wirtz PD: High school basketball knee ligament injuries. J Iowa med Soc 1982;72:105-106.

51 Tudor RB: Acute subdural hematoma following a blow from a basketball. Am J Sports Med 1979;7:136.

52 National Center for Catastrophic Sport Injury (NCCSI): 21st Annual report. NCCSI 2004; www.unc.edu/depts/nnccsi/ReportDataTables.htm.

53 Mueller FO, Cantu RC: Catastrophic injuries and fatalities in high school and college sports, fall 1982-spring 1988. Med Sci Sports Exerc 1990;22:737-741.

54 Mueller FO: Catastrophic head injuries in high school and collegiate sports. J Athl Train 2001;36:312-315.

55 Maron BJ, Gohman TE, Aeppli D: Prevalence of sudden cardiac death during competitive sports activities in Minnesota high school athletes. J Am Coll Cardiol 1998;32:1881-1884.

56 Maron BJ, Shirani J, Poliac LC, Mathenge R, Roberts WC, Meuller FO: Sudden death in young competitive athletes: Clinical, demographic and pathological profiles. JAMA 1996;276:199-204.

57 Serdaroglu G, Levent E, Yurtseve S, Calkavur T, Yunten N, Aydogdu S: Dissection of aorta: A pediatric case report. Turk J Pediatr 2002;44:254-257.

58 Becker JM, Rogers J, Rossini G, Mirchandani H, D’Alonzo GE: Asthma deaths during sports: Report of a 7-year experience. J Allergy Clin Immunol 2004;113:264-267.

59 Chow AY, Goldberg MF, Frenkel M: Evulsion of the optic nerve in association with basketball injuries. Ann Ophthalmol 1984;16:35-37.

60 Friedman SM: Optic nerve avulsion secondary to a basketball injury. Ophthalmic Surg Lasers 1999;30:676-677.

61 Axe MJ, Newcomb WA, Warner D: Sports injuries and adolescent athletes. Del Med J 1991;63: 359-363.

62 Rider SP, Hicks RA: Stress, coping and injuries in male and female high school basketball players. Percept Mot Skills 1995;81:499-503.

63 Watson AWS: Sports injuries during one academic year in 6799 Irish school children. Am J Sports Med 1984;12:65-71.

64 Hewett TE, Riccobene JV, Lindenfeld TN, Noyes FR: The effect of neuromuscular training on the incidence of knee injury in female athletes: A prospective study. Am J Sports Med 1999;27:699-706.

65 Ford KR, Myer GD, Hewett TE: Valgus knee motion during landing in high school female and male basketball players. Med Sci Sports Exerc 1999;35:1745-1750.

66 Newsome PRH, Tran DC, Cooke MS: The role of the mouthguard in the prevention of sportsrelated dental injuries: A review. Int J Paediatr Dent 2001;11:396-404. 
67 Johnson DW, Parker BJ: Athletic mouth guards - One town's approach. J Calif Dent Assoc 1993;21:39-42.

68 Micheli LJ, Metzl JD, DiCanzio J, Zurakowski D: Anterior cruciate ligament reconstructive surgery in adolescent soccer and basketball players. Clin J Sport Med 1999;9:138-141.

69 Young ML, Cohen DA: Self-concept and injuries among high school basketball players. J Sports Med 1981;21:55-61.

70 McNutt T, Shannon SW, Wright JT, Feinstein RA: Oral trauma in adolescent athletes: A study of mouth protectors. Pediatr Dent 1989;11:209-213.

71 Foster M, March K: Increasing mouthguard use. A pilot campaign for junior basketball and rugby. Aust Endod J 1999;25:87-89.

72 Jalleh G, Donovan RJ, Clarkson J, March K, Foster M, Giles-Corti B: Increasing mouthguard usage among junior rugby and basketball players. Aus NZJ Public Health 2001;25:250-252.

73 American Academy of Family Physicians: Policy statement - Sports medicine 2004;www.aafp.org.

74 Grubbs N, Nelson RT, Bandy WD: Predictive validity of an injury score among high school basketball players. Med Sci Sports Exerc 1997;29:1279-1285.

75 Cook JL, Khan KM, Kiss ZS, Purdam CR, Griffiths L: Prospective imaging study of asymptomatic patellar tendinopathy in elite junior basketball players. J Ultrasound Med 2000;19:473-479.

76 Cook JL, Khan KM, Kiss ZS, Purdam CR, Griffiths L: Reproducibility and clinical utility of tendon palpation to detect patellar tendinopathy in young basketball players. Br J Sports Med 2001:35:65-69.

Professor Peter Harmer

Exercise Science-Sports Medicine

Willamette University, Salem, OR 97301 (USA)

Tel. +1 503370 6470, Fax +1 503370 6379, E-Mail pharmer@willamette.edu 